BBA $75^{232}$

\title{
ZONAL DENSITY GRADIENT ELECTROPHORESIS OF INTRACELLULAR MEMBRANES OF BRAIN CORTEX
}

OTTO Z. SELLINGER AND ROBBRT N. BUORENS

Mental Health Research Institute, Lniversity of Michigan Hedical Center, Ann Arbor, Mich. (U.S.A.)

(Received September r6th, ro68)

SUMMARY

Rat cerebral cortex was homogenized in a sucrose-free medium and a number of intracellular membrane fractions were isolated therefrom by means of differential and density-gradient centrifugation. The mitochondrial and microsomal membrane fractions, as well as the separated rough and smooth endoplasmic reticulum components of the latter, were subjected to zonal density gradient electrophoresis. With this technique it was possible to determine the electrokinetic profile of the membranes contained in each fraction. The application of zonal density gradient electrophoresis to the membrane populations obtained by density-gradient centrifugation revealed marked differences in electrophoretic mobility between them which correlated directly with both their membrane-bound $N$-acetylneuraminic acid content and their acetylcholinesterase (EC 3.I.I.7) activity. The fraction containing membranes in which both of these components were highest and, hence, presumably synaptic in derivation, was isolated as a single, homogeneous electrophoretic peak.

\section{INTRODUCTION}

The study of the intracellular organization of brain cortex lads greatly benefitted in recent years, from the application of centrifugal techniques ${ }^{1-4}$ which have led to the isolation of nerve endings ${ }^{1,5,6}$, synaptic vesicles ${ }^{7,8}$ and other cellular inclusions ${ }^{9-11}$ characteristic of this tissue. More recently, by using hypotonicity $y^{12-14}$ and detergents ${ }^{15}$ and by suitably manipulating the ionic environment ${ }^{16}$, it has been possible to isolate several cortical membrane populations to which specific intracellular derivations have been assigned on the basis of one or more morphological ${ }^{17}$, enzymatic ${ }^{12}$, analytical ${ }^{18,19}$ and pharmacological ${ }^{20,21}$ criteria. These studies have disclosed differences in appearance $^{22}$, chemical composition, enzyme content ${ }^{23}$ and drug-binding capacity of the various cortical intracellular membranes but, unlike comparable studies of plasma membranes ${ }^{24}$ derived from erythrocytes ${ }^{25}$, liver cells $s^{25,26}$, fibroblast ${ }^{24}$ or specialized Escherichia coli mutants ${ }^{27}$, they have not sought to exploit intrinsic differences in overall physical properties which might exist between them.

In the present study, the electrophoretic negativity as imparted to the surface of intracellular membranes of rat brain cortex by protein-bound $N$-acetylneuraminic acid $^{18,26,28}$ is exploited in an attempt to identify those factors which might be operative 
in the conferring to and the maintenance by, a given membrane, of its structural and functional specificity. Zonal density gradient electrophoresis ${ }^{29}$, complemented by assays of membrane marker enzymes are the techniques used. The accompanying paper $^{30}$ deals with the effects of enzymatic digestion of one membrane type, the synaptic membrane, on its electrophoretic behavior.

MATERIALS AND METHODS

Animals

Adult rats $(200-300 \mathrm{~g})$ of both sexes were used.

Chemicals and enzymes

Sucrose (enzyme grade) and bovine serum albumin: Mann Research Labs., New York; glycerol (A.R.) : Baker and Co., Philipsburg, N. J.; acetylthiocholine iodide and 2-( $p$-iodophenyl)-3-( $p$-nitrophenyl)-5-phenyltetrazolium chloride: Dajac Laboratories, Philadelphia; 5,5'-dithio-bis-(2-nitrobenzoic acid) : K and K Laboratories, Plainview, N.Y.; L-glutamohydroxamate: Sigma Chemical, St. Louis, Mo.; acetylcholinesterase (EC 3.I.I.7) (Electrophorus electricus), chromatographically purified, Batch 6 JA: Worthington Biochemical, Freehold, N.J.; ADP and sheep brain glutamine synthetase (EC 6.3.I.2), Lot No. X-I602-C: P-L Biochemicals, Milwaukee, Wisc. All other reagents were of the best commercial grade available.

\section{Centrifugal fractionation of rat cerebral cortex}

(A) Nerve ending, mitochondrial and lysosomal membranes. The dissected and weighed brain cortex from one rat was homogenized in ice-cold $20 \mathrm{mM}$ Tris-HCl buffer $\left(\mathrm{pH} 7.2\right.$ ) containing Io mM magnesium acetate (Soln. E) ${ }^{16,31}$ at about I300 rev./min for $30 \mathrm{sec}$, the volume was adjusted to yield a Io-I5\% (w/v) homogenate, and the suspension was centrifuged for 1o min at $25000 \times g$ (Sorvall rotor SS-34). The sediment was resuspended in half the original volume of Soln. $E$ and the above centrifugation was repeated once. The final pellet, suspended in $2 \mathrm{ml}$ of $0.25 \mathrm{M}$ sucrose, was layered on top of $15 \mathrm{ml}$ of $0.9 \mathrm{M}$ sucrose which, in turn, rested on Io $\mathrm{ml}$ of $\mathrm{I} .4 \mathrm{M}$ sucrose. Centrifugation (63000 $\times g$, 30 min, Spinco rotor SW-25.I, brake off) separated off myelin (band floating on $0.9 \mathrm{M}$ sucrose). The band collecting at the $0.9-\mathrm{I} .4 \mathrm{M}$ sucrose interface was pelleted by centrifugation at $269000 \times g$ for $30 \mathrm{~min}$ (Spinco rotor 65) and the pellet suspended in $2 \mathrm{ml}$ of $0.25 \mathrm{M}$ sucrose. This suspension, containing nerve ending, mitochondrial and lysosomal membranes, was placed on top of a 3-step discontinuous sucrose gradient consisting of $\mathrm{ro} \mathrm{ml}$ of $\mathrm{I} .4 \mathrm{M}$ sucrose, $7 \mathrm{ml}$ of $\mathrm{I.2} \mathrm{M}$ sucrose and $7 \mathrm{ml}$ of I.o M sucrose (Gradient A) or of $9 \mathrm{ml}$ each of I.3, I.2 and I.I M sucrose (Gradient B). Centrifugation $(2 \mathrm{~h}, 63500 \times g$, rotor $\mathrm{SW}-25 . \mathrm{I})$ yielded a band at every sucrose interface plus a pellet, $\mathrm{M}_{\mathrm{p}}$. For electrophoresis, the gradient bands (referred to as $\mathrm{M}_{\text {sucrose molarity }}$ ) were pelleted $(269000 \times g, 30 \mathrm{~min})$ and were suspended, together with Pellet $M_{p}$, in a small volume 'heavy' buffer (prepared by bringing $432 \mathrm{ml}$ of glycerol to 1 with $0.05 \mathrm{M}$ Tris- $\mathrm{HCl}$ buffer, $\mathrm{pH}$ as indicated in the text).

(B) Microsomal membranes. The brain cortex homogenate, prepared in Soln. E, was centrifuged directly at $25000 \times g$ for ro min and the sediment was washed once. The pooled supernatants were centrifuged at $269000 \times g$ for $30 \mathrm{~min}$ and the resulting, translucent pellet consisting of the microsomal fraction ${ }^{16,31}$ was suspended for electrophoresis as above in $\mathrm{A}$. 
(C) Smooth and rough endoplasmic reticulum. These nembrane fractions were obtained by a recently described technique ${ }^{16,31}$. Briefly, microsomal pellets were suspended by manual homogenization in Soln. E containing $15 \mathrm{mM} \mathrm{CsCl}$ and the suspension ( $\mathrm{I} .7 \mathrm{ml}$ ) was layered on $3.3 \mathrm{ml}$ of $\mathrm{I} .3 \mathrm{M}$ sucrose containing $\mathrm{I} 5 \mathrm{~m} \mathrm{M} \mathrm{CsCl}$. The tubes were centrifuged in the $\$ W-50 L$ Spinco rotor at 204000 s for 3 h. The smooth membrane fraction was collected from the interface, while the rough membrane fraction was recovered as a pellet.

(D) Zonal density gradient electrophoresis. This was carried out in the jacketed column electrophoresis apparatus (Model 3340C) as supplied for density gradient filling (LKB Instruments, Rockville, Md.). The design and operation of the apparatus have been described in detail by Sirevsiox ${ }^{29}$. The entire central vertical colum $\left(7.5 \mathrm{~cm}^{2}\right.$ fo cm) was filled with the density gradient prepared according to DAVIs, SANTEX AXI) AGraNoF ${ }^{32}$ by mixing equal volumes (2 times $\left.140 \mathrm{ml}\right)$ of 5 and $20 \%$ glycerol $(\mathrm{w} / \mathrm{v})$ in $0.0045 \mathrm{MI}$ Tris $\mathrm{HCl}$ buffer at the desired $\mathrm{pH}$. Separations were carried out in $0.05 \mathrm{M}$

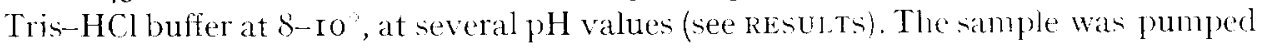
into the apparatus through the bottom capillary after proper density adjustment and it lavered itself as a sharp zone on top of the 'heavy' buffer filling the right-arm electrode tube. Electrophoresis was carried out with reversed polarities, so that migration upward was to the anode.

(E) Density gradionts. Linear sucrose density gradients were prepared according

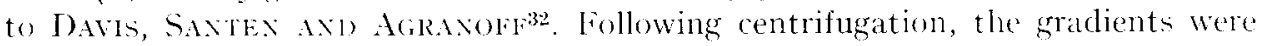
extruded through a hole in the bottom of the centrifuge tube. Following clectrophoresis, 50\% glycerol which was slowly pumped into the apparatus, lifted the derisity gradient for extrusion through the top of the column. About 50 fractions (6 $\mathrm{ml} / \mathrm{tube}$ ) were collected.

(F) Enzl'me assays. All enzyme activities are expressed as the net absorbance (A) (see details in the legends to the figures) at 490 and $500 \mathrm{~mm}$, respectively, for succinate dehydrogenase ${ }^{10}\left(\mathrm{EC}\right.$ I.3.99.I) and glutamine synthetase ${ }^{30}$, or as $\Delta . A$ at $4 \mathrm{I} 2 \mathrm{~nm}$ for acetylcholinesterase ${ }^{10}$.

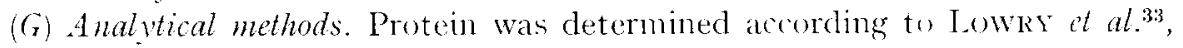
with bovine serum albumin as standard.

(H) Purification of glutamine synthetase from sheep brain. The procedure outlined for pig brain by SCHNACKERZ ANI) JAEXICKE ${ }^{34}$ was carried up to and including the $40 \%$ saturation in $\left(\mathrm{NH}_{4}\right)_{2} \mathrm{SO}_{4}$ step.

KESULTS

Whether isolated from rat brain cortex ${ }^{17}$, lobster leg nerve ${ }^{35}$, eel electric tissue ${ }^{36}$, or canine caudate nucleus ${ }^{37}$, the discrete bands collected from the sucrose interfaces following centrifugation in discontinuous density gradients, differ both morphologically ${ }^{17}$ and in acetylcholinesterase ${ }^{38}$ and bound $N$-acetylneuraminic acid contents ${ }^{18}$. The results of the present experiments confirm the preferential association of acetylcholinesterase with the light, synaptic membranes (Band $M_{1.0}$, Gradient $A$; Band $M_{1.1}$, Gradient $B$, see METHOLS) and emplasize the relative lack of concentration of this activity in the mitochondrial membranes $\left(\right.$ Band $\mathrm{M}_{1.4}$ and Pellet $\left.\mathrm{M}_{1}\right)$ in which succinate dehydrogenase concentrated. Glutamine transferase, as noted previously ${ }^{23,38}$, associated rather broadly with several of the bands and exhibited no clearly defined relative specific activity peak. 
Electrophoresis of the primary fraction containing nerve ending, mitochondrial and lysosomal membranes

In preliminary experiments, suspensions of this fraction were subjected to electrophoresis for the purpose of establishing optimal resolution conditions. The duration of the run, the voltage and the $\mathrm{pH}$ of the buffer filling the electrodes and the gradient column were the chief variables. Fig. I (A, B and D) shows the electrophoretic profiles of the membranes rum in $0.05 \mathrm{M}$ Tris buffer at $\mathrm{pH} \mathrm{7.2,} \mathrm{7.4,} 7.7$ and 8.0 (measured at $25^{\circ}$ ) under otherwise closely similar conditions of time and voltage $(5.75-6 \mathrm{~h}, 600 \mathrm{~V})$, while Fig. IC illustrates the effect of prolonging a $\mathrm{pH} 7.4$ run from 6-9.75 h. A $1 \mathrm{l} 6$ - $\mathrm{l}$ profiles, but especially the one obtained at $\mathrm{pH} 7 \cdot 4$, reveal the presence of at least two populations, with an additional slow component visible as a shoulder (ligs. $\mathrm{IA}$ and B, Tubes $24-35$; Fig. $\mathrm{ID}, \mathrm{pH} 7.7$, Tubes $\mathrm{I} 5-25$ and $\mathrm{pH}$ 8.o, Tubes $2 \mathrm{I}-3 \mathrm{I}$ ) and at $9.75 \mathrm{~h}$ as a resolved peak (Fig. IC, Tubes $25-35$ ).
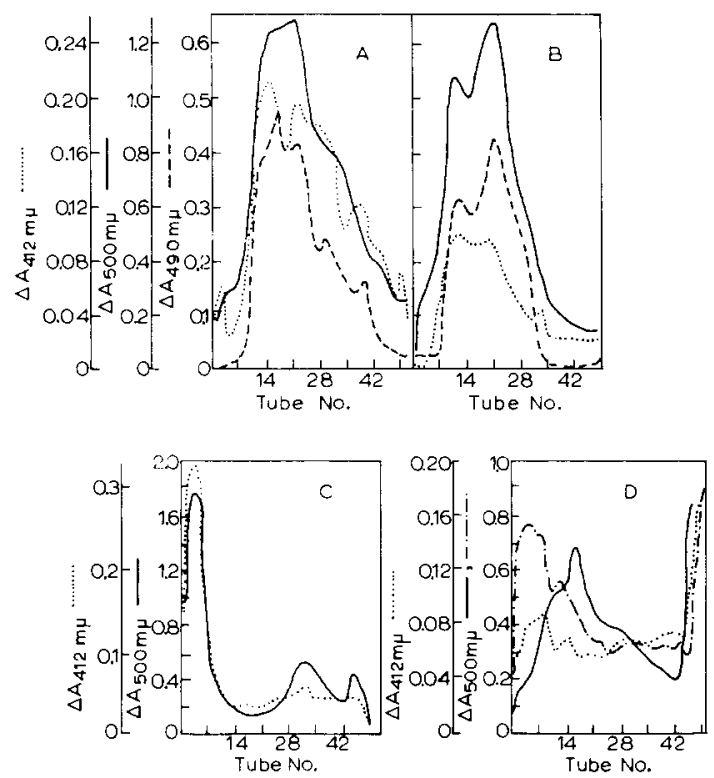

IFig. I. Zonal density gradient electrophoresis of the fraction containing nerve ending, mitochondrial and lysosomal membranes: effects of $\mathrm{pH}$ and run duration on the electrokinetic profiles of marker enzymes and of protein. $1 A_{412 \mathrm{~nm}}$ : acetylcholinesterase; $A_{500 \mathrm{~nm}}$ : glutamine synthetase and $A_{490 \mathrm{~nm}}$ : succinate dehydrogenase. A. pH $7.2,6 \mathrm{~h}, 600 \mathrm{~V} ; \mathrm{B} . \mathrm{pH} 7.4,6 \mathrm{~h}, 600 \mathrm{~V} ; \mathrm{C}, \mathrm{pH} 7.4$, $9.75 \mathrm{~h}, 600 \mathrm{~V} ; \mathrm{D} . \mathrm{pH} 7.7$ (acetylcholinestcrase and glutamine synthetase indicated by dotted and (otted-dashed line, respectively) and $\mathrm{pH}$ s.o (glutamine synthetase indicated by solid line), $6 \mathrm{~h}$, $600 \mathrm{~V}$. The following peaks of protein were found: A, Tubes $3, \mathrm{I} 5,2 \mathrm{I}, 29$ and 43 ; B, Tubes I I, $2 \mathrm{I}$ and $3 \mathrm{I}$; $\mathrm{C}$, Tubes $+33,46$ and $\mathrm{D}(\mathrm{pH} 8.0)$, Tubes II, I5, I9, 25 and 47 . The assay conditions (aliquot taken and time of incubation) werc: acetylcholinesterase $(0.3 \mathrm{ml}, 3 \mathrm{~min})$; glutamine synthetase $(0.25 \mathrm{ml}, \mathrm{I} \mathrm{h})$; succinate dehydrogenase (o.I $\mathrm{ml}, 20 \mathrm{~min})$.

\section{Electrophoresis of membrane subfractions}

The membrane subfractions were subjected to electrophoresis at $\mathrm{pH} 7.4$ (Gradient A, Figs. 2A-C) and $\mathrm{pH} 7.2$ (Gradient B, Figs. 2D-G). At the former $\mathrm{pH}$, the light $\left(\mathrm{M}_{1.0}\right)$ membranes migrated toward the anode slightly faster than the heavier $\left(\mathrm{M}_{1.4}\right)$ membranes, this trend being even more accentuated at $\mathrm{pH} 7.2$, as indicated by the 
respective peaks of enzyme activity in Tubes $\mathrm{I} 3\left(\mathrm{D}\right.$, Fraction $\mathrm{M}_{\mathbf{1 . 3}}$ ) and 23 ( $\mathrm{F}$, Fraction $\mathrm{M}_{1.3}$ ). Fraction $\mathrm{M}_{1.1}$ (Fig. $2 \mathrm{D}$ ) consistently gave the most homogeneous profile, viz. one rather symmetrical peak of glutamine synthetase, acetylcholinesterase and protein. To demonstrate that acetylcholinesterase under this peak is still membrane-associated, the contents of the appropriate effluent tubes were pooled and lyophilized after removal of glycerol by dialysis against $0.00 \mathrm{I} 2 \mathrm{M}$ Tris buffer, $\mathrm{pH}$ 7.2. A suspension of the residue in $0.05 \mathrm{M}$ Tris buffer, $(\mathrm{pH} 7.2)$ was layered on a $5.20 \%$ linear sucrose gradient which was centrifuged at $63500 \times \mathrm{g}$ for $\mathrm{I} 3 \mathrm{~h}$. Most of the acetylcholinesterase activity was recovered in the pellet.
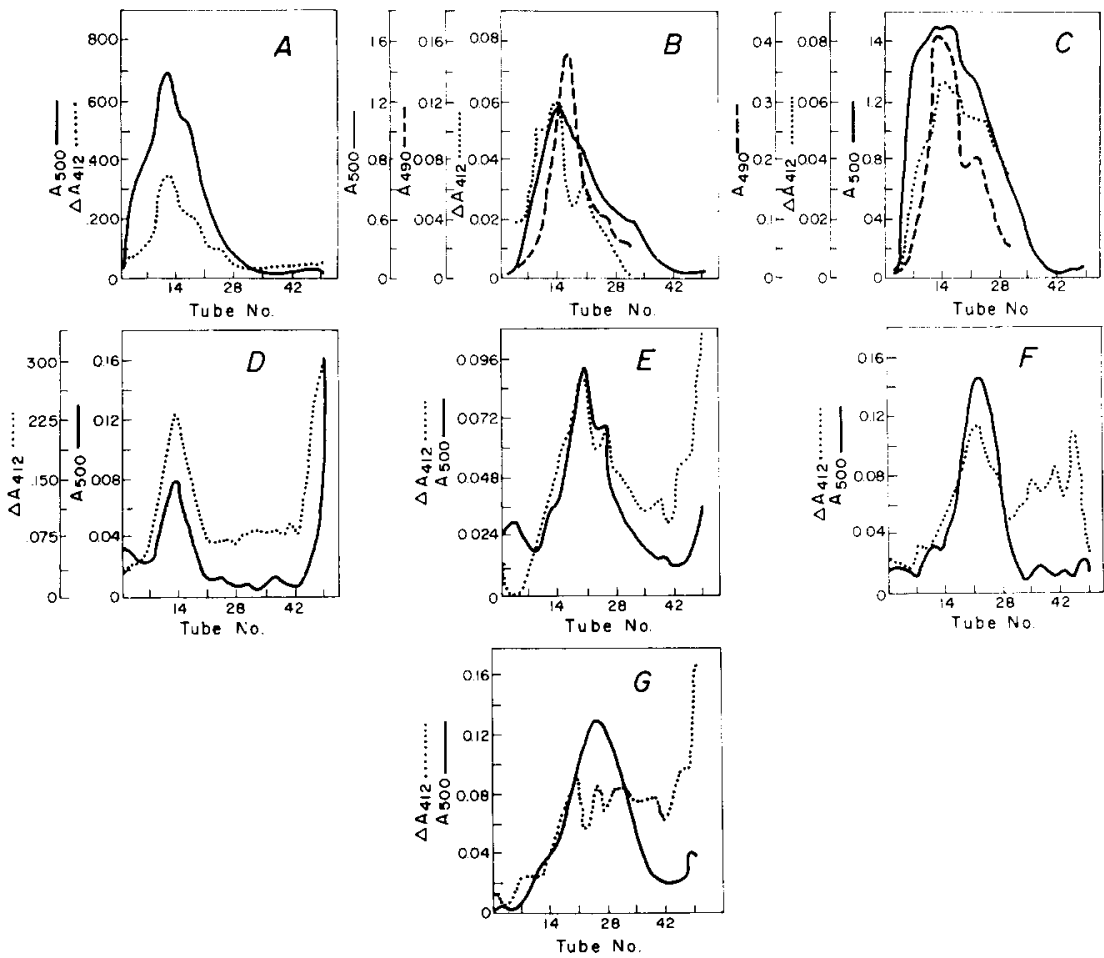

Fig. 2. Zonal density gradient electrophoresis of membrane subfractions isolated in density gradients $A(A-C)$ and $B(D-G)$ (see meruons). Electrophoresis was for $6 \mathrm{~h}$ at $600 \mathrm{~V}$ and $\mathrm{pH} 7 \cdot+$ $(\mathrm{A}-\mathrm{C}$ ) or for $\mathrm{II}-12 \mathrm{~h}$ at $300 \mathrm{~V}$ and $\mathrm{pH} 7.2$ (I) - ( $\mathrm{r})$. The explanation of ordinate symbols is given in the legend to Fig. I. Dotted lines refer to acetylcholinesterase, solid lines to glutamine synthetase and dashed lines to succinate dehydrogenase. A. Membrane fraction $\mathbf{M}_{1.0}$ (for analytical and morphological detaits of this and other fractions, see refs. 12, i 8 and 38 as well as the accompanying paper ${ }^{30}$ ). B. Membrane fraction $M_{1.2}$. C. Membrane fraction $M_{1.4}$. D. Membrane fraction $M_{1.1}$. E. Membrane fraction $\mathrm{M}_{1.2}$. F. Membrane fraction $\mathrm{M}_{1.3}$. G. Fraction $\mathrm{M}_{\mathrm{p}}$ (pellet). The following peaks of protein were found: A, 'Tube I 2 . B, Tube I 5. C, Tubes I 5-I 7. I), Tubes I 3 and 49 . E, Tubes $\mathrm{I}, \mathrm{I9}-23,29,39$ and 49 . F. Tubes $\mathrm{I}, 9-\mathrm{I} \mathrm{I}, 2 \mathrm{I}, 3 \mathrm{I}, 39$ and 47 . G. Tubes $\mathrm{I}, 25,29-33$ and 49. The assay conditions (see legend, Fig. I) were: Acetylcholinesterase: $\mathrm{A}(\mathrm{I} \mathrm{ml}, 3 \mathrm{~min}) ; \mathrm{B}$ and $\mathrm{C}(0.4 \mathrm{ml}, 3 \mathrm{~min})$;

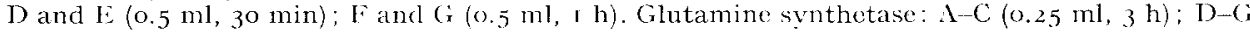
$(0.25 \mathrm{ml}, \mathrm{f}$ h). Succinate dehydrogenase $(0.25 \mathrm{ml}, 2 \mathrm{~h})$.

\section{Electrophoresis of the microsomal fraction and subfractions}

The profiles of the microsomal membranes and of the smooth and rough endoplasmic reticulum components are shown in Fig. 3. They reflect an appreciable 
fragmentation of the membranous material containing the acetylcholinesterase activity and a surprising lack of some among the membrane elements which concentrate the glutamine synthetase activity.

\section{Electrophoresis of the high-speed soluble fraction and of purified preparations of glutamine} synthetase and acetylcholinesterase

The soluble glutamine synthetase component of rat brain cortex and the partially purified preparation of sheep brain glutamine synthetase (Fig. 4, Curves A
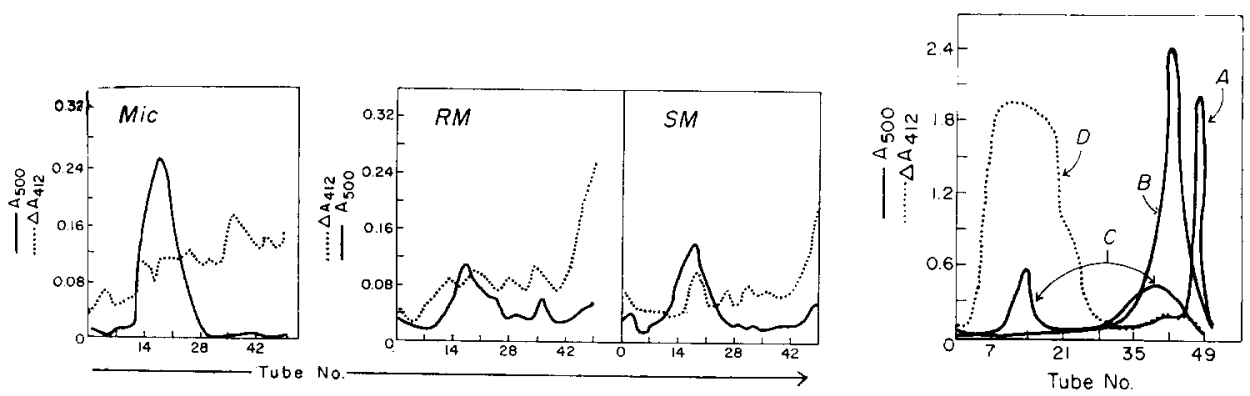

Fig. 3. Zonal density gradient electrophoresis of the membranes of the microsomal fraction (Mic) and of its rough and smooth membrane subfractions (RM and SM). For explanation of ordinate symbols, see the legend, Fig. I. Dotted lines: acetylcholinesterase; solid lines: glutamine synthetase. Conditions: $\mathrm{pH} 7.2, \mathrm{I} 2 \mathrm{~h}, 300 \mathrm{~V}$. The following peaks of protein were found: Mic, Tubes I3, 2 I, 29, 33, 4 I-45 and 49. The assay conditions (see legend, Fig. I) were: acetylcholinesterase (o.5 ml, $30 \mathrm{~min})$; glutamine synthetase $(0.25 \mathrm{ml},+\mathrm{h})$.

Fig. 4. Zonal density gradient electrophoresis of rat brain cortex high-speed supernatant and of partially purified preparations of glutamine synthetase and acetylcholinesterase. The ordinate symbols, as described in the legend, Fig. I. Dotted line: acetylcholinesterase; solid lines: glutamine synthetase. Conditions: $\mathrm{pH} 7.2, \mathrm{I} 2 \mathrm{~h}, 300 \mathrm{~V}$. A, rat brain high-speed supernatant glutamine synthetase; B, sheep brain glutamine synthetase ${ }^{34}$; C, commercial glutamine synthetase; I), E. electricus acetylcholinesterase. All commercial enzyme preparations were dissolved in 'heavy' buffer immediately prior to electrophoresis, while all enzyme suspensions were density-adjusted for electrophoresis by the addition of glycerol.

and B) failed to migrate. The commercial glutamine synthetase preparation (Curve C), by contrast, exhibited two peaks, one coinciding with the soluble and the other with the particulate enzyme of rat brain, as seen in Figs. 3 and 4. Commercial E. electricus acetylcholinesterase exhibited a single, broad peak (Fig. $4 \mathrm{D}$ ), close to the anodic terminal, indicating the presence of net negative charges in the protein. Conversely, when a suspension (0.05 M Tris buffer $(\mathrm{pH} 7.2)$ ) of the same enzyme was gradientcentrifuged $\left(5^{--20} \%\right.$ sucrose, $\left.I 5.5 \mathrm{~h}, 63500 \times \mathrm{g}\right)$, the activity peaked near the top of the gradient.

DISCUSSION

The intermembrane distribution of the assayed enzyme activities indicates the preferential association of acetylcholinesterase with the lightest* of the isolated membrane populations $\left(\mathrm{M}_{1.0}\right.$ : Gradient $\mathrm{A} ; \mathrm{M}_{1.1}$ : Gradient $\mathrm{B}$ ), in confirmation of the

* In the present study, the low cutoff sucrose molarity has been intentionally set at I.O M, so as to avoid, as much as possible, contamination by myclin. 
recent findings of Rolniguez 1 E LoREs ARxAlz et al. ${ }^{38}$ (rat cerebral cortex), of SEllivaer et al.37 (dog caudate nucleus) and of Keivitz Axi) Weisch ${ }^{35}$ (lobster leg nerve), but in contrast to the observation of KisLL ${ }^{36}$ who found that the membrane fraction of the electric eel which is rich in acetylcholinesterase, and which, most probably, also contains fragments of the cell membrane collects at higher sucrose densities (I.5-I.S I M interface). Succinate dehydrogenase, like monoamine oxidase ${ }^{38}$, a marker of the mitochondrial membrane, exhibited relative specific activity peaks in Fractions $\mathrm{I}_{1 .+}$ and $\mathrm{M}_{\mathrm{p}}$ while glutamine transferase showed high values throughout fractions $\mathrm{M}_{1.2}, \mathrm{M}_{1.3}, \mathrm{M}_{1.4}$ and $\mathrm{M}_{\mathrm{p}}$ (cradient $\mathrm{B}$ ) but not in liractions $\mathrm{M}_{1.0}$ and $\mathrm{H}_{1.1}$. These findings lend further credence to the previously suggested possibility ${ }^{12,39}$, viz. that, in addition to being associated with the membranes of the endoplasmic reticulum ${ }^{16,23,+10}$ (microsomal fraction) and the glial and neuronal membranes ${ }^{41}$, glutamine synthetase is also a component of the mombrane of the nom-cholinergic nerve endings (liaction D) $)^{7}$.

The results of the above experiments (Iigs. I + f) show that with the techique of zonal density gradient electrophoresis it is possible to examine and to discrininate between the electrokinetic mobilities of intracellular membrane populations and by so doing extend the use ful ranget-44 of this technique.

The electrokinetic and the protein clution profiles (for details on the latter, see the legends to the appropriate figures) of the fraction containing the nerve ending, mitochondrial and lysosomal membranes reveal its complexity. Thus, two major protein peaks, coinciding with the two regions of high acetylcholinesterase, glutamine sinthetase and succinate dehydrogenase activity were detected at $\mathrm{pH} 7.2$ and $7 .+$ (Figs. I $A$ and $B$ ), while four regioms of protein concentration and glutamine synthetase activity appeared at $\mathrm{p} H \mathrm{H}$ S.O (lig. ID, solid line).

Electrophoresis of the subfractions (Lig. 2) illustrates the method's resolving power. Thus, the faster moving of the two peaks seen in Fig. IB (Tubes 9-I3) was the main component of liactions $\mathrm{M}_{1.0}$ and $\mathrm{M}_{1.2}$ (IFigs. 2A and $\mathrm{B}$ ), while the slower moving component (Tubes $15-23$ ) appeared as a shoulder common to the profiles of all three subfractions $(\mathrm{pH} 7.4)$. Similarly, the complex $\mathrm{pH} 7.2$ profile (Fig. IA) with acetylcholinesterase and glutamine synthetase peaks in Tubes I $3-17$ and Tubes $20-23$ was resolved by electrophoresis of the subfractions (liig. 2) into the single, fast-moving peak with both activities ( $\mathrm{Fig}$. $2 \mathrm{D}$, Fraction $\mathrm{M}_{1.1}$, Tubes I I-I.5) and the slower-moving component with a peak in Tubes $20-25$ (Fraction $\mathrm{M}_{1.3}$, Fig. $2 \mathrm{~F}$ ); the profile of Fraction $M_{1.2}\left(\right.$ firg. $2 \mathrm{E}$ ) reflects a composition intermediate between those of liractions $M_{1.1}$ and $\mathrm{M}_{1.33}$.

The electrophoretic protiles of liractions $\mathrm{M}_{1 \cdot 3}$ and $\mathrm{N}_{1.4}$ (Figs. $2 \mathrm{l}^{*}$ and $\mathrm{G}$ ) and those of the microsonal, rough and smooth endoplasmic reticulum fractions (lig. 3 ) disclose a considerable dispersion of charges among the acetylcholinesterase-bearing membranes, and virtually none among the membranes bearing glutamine synthetase. That the electrophoretic mobility of a membrane may indeed be correlated with it: content of bound $N$-acetyheuraminic acid and, hence, with it net charge, is illustrated by the profiles of Fractions $\mathrm{M}_{1.1}$ and $\mathrm{M}_{1.2}$ containing membranes known to be the richest in acetylcholinesterase ${ }^{12,3 x}$ and in bound $N$-acety-lneuraminic acid see accontpanying paper ${ }^{30}$ ); predictably, therefore, these fractions migrated the most rapidly when subjected to electrophoresis at $\mathrm{pH} 7.2$.

Thus, the technique of zonal density gradient electrophoresis adequately reveals 
the 'charge homogeneity' of a given membrane population; yet it visibly fails to discriminate between the two alternatives, viz. do single peak profiles reflect the co-presence of two membrane types of equal net charge, each bearing a single enzyme activity or do they, instead, denote a single membrane type bearing two activities? In the particular instance of Fraction $M_{1.1}$ it is possible to opt for the former alternative on the basis of the additional information provided, i.e., the widely different relative specific activity values of acetylcholinesterase and glutamine synthetase in this fraction. Clearly, however, a thorough examination of the morphology $y^{15,38,45}$ of the membrane types comprising each electrophoretically separable membrane fraction and subfraction would provide much additional information on this point.

\section{ACKNOWLEDGEMENTS}

This research was supported by a grant from the U.S. Public Health Service (NB-o6 294). The excellent technical assistance of Mrs. Linda Nordrum is gratefully acknowledged.

\section{RELERENCLS}

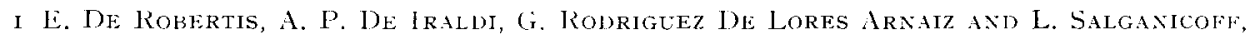
I. Neurochem., 9 ( 1962$) 23$.

2 V. P. Whitraker, Progr. Biophys. Mol. Biol., i $5(1965) 39$.

3 E. De Robertis, Science, i56 (1967) 907 .

4 K. Von Husgen, H. R. Mahler and W. J. Mloore, J. Biol. Chem., 243 (I963) I4I5.

5 E. Gray and V. P. Whittaker, J. Anat. London, 96 (1962) 79.

6 M. Kurokawa, T. Sakamoto and M. Kato, Biochem. J., 97 (1965) 833.

7 L. De Robertis, G. Rodriguez de Lores Arsaiz, L. Salgaxicofy, A. P. Ife Iraldi anir L. M. Ziener, $J$. Neurochem., ro (I963) 225.

8 V. P. WhitTaker and M. N. Sheridan, J. Neurochem., I 2 (1965) 363.

9 (). Z. Sellinger, D. L. Rucker ANd li. De Balbian Verster, J. Neurochem., i I (1964) 27 I.

io (). Z. Sellinger and R. A. Hiatt, Brain Res., 7 (1968) IgI.

i s. E. Kornguth, J. Walberg-Anderson, (i. Scott and H. Kubinski, Exptl. Cell Re's., +5 $(1967) 656$.

I 2 E. De Robertis, M. Alberict, G. Ronrigi'ez De Lores arnaiz aNd J. M. Azcurra, Life Sici., $5(1966) 577$.

I 3 V. P. WhitTaker, Ann. N. Y. Acad. Sci., I 37 (1966) 982.

it F. De Balbian Verster, O. Z. Sellinger axi J. C. Harkin, J. Cell Biol., 25 (I965) 69.

i 5 S. Fiszer a.jd E. De Robertis, Brain Res., 5 (Ig6 7 ) $3 \mathrm{I}$.

if O. Z. Sellinger avb J. M. Azcurra, Macromolecules and the Function of the Neuron, Intern. Symp., Liblice, I967, Excerpta Med. Found., I968, p. 256.

I7 E. De Robertis, J. M. Azcurra AND S. Tiszer, Brain Res., 5 (1967) 45.

is E. G. Lapetina, E. F. Soto axil E. De Robertis, Biochim, Biophys. Acta, I35 (1967) 33.

ig E. G. Lapetina, E. F. Soto axd J. De Robertis, J. Neurochem., I5 (I968) 437.

20 J. . I. Azcurra and E. De Robertis, Intcm. J. Neuropharmacol., 6 (I967) I 5.

2 I E. De Robertis, S. Fiszer and E. T. Soto, Science, 158 (1967) 928.

22 V. P. WhitTAKER, Biochem. J., IO6 (I968) +12 .

23 O. Z. Sellinger, F. De Balbiax Verstir, R. J. Suldivan and C. Lamar, Jr., J Neumchem., I 3 (I966) 5 O I.

24 L. Warren, M. C. Glick A.ND M. K. Nass, J. Cellutar Comp. Physiol., 68 (1966) 269.

25 D. F. Hoflzl Wallach, in B. D. Davis, The Specificity of Cell Surfaces, Prentice Hall, Englewood Cliffs, 1967, p. 129.

26 I. L. Benewetti and P. Eumelot, $J$. Cell Sici., 2 ( 1967$) 499$.

27 H. R. Kaback and E. R. Staptman, $J$. Biol. Chem., 243 (1968) 671.

28 M. W. Spence and L. S. Wolfe, Can. J. Biochem., +5 (1967) $67 \mathrm{I}$.

29 H. Svensson, in P. AleXander Axi R. J. Block, A Laboratory Mannal of A nalytical Methods in Protein Chemistry Including Polypeptides, Pergamon Press, Oxford, 1960, p. I93.

3o O. Z. Sellinger, R. N. Borexs axd L. N. Nordrum, Biochim. Biophys. Acta, I73 (r969) I85. 
3 I O. Z. Sellinger, J. M. Azcurra axd W. G. Ohlssox, J. Pharmacol. Exptl. Therap., I64 (I968) 212.

32 (i. A. Davis, R. J. Santen and B. W. Agraxoff, Anal. Biochem., i I (I965) I 53.

33 (). H. Lowry, N. J. Rosebrough, A. I. Farr axd I'. J. Kandale, J. Biol. Chem., i93 (I95I) 265 .

34 K. Schnacherz and L. JaEnicke, $Z$. Physiol. Chim., 377 (1960) i 28.

35 H. Kewitz and i. Welsch, Arch. Expll. Pathol. Phammacol., 258 (I967) 1.

36 A. Karlin, J. Cell Biol., $25(1965)$ i 59.

37 O. Z. Sellinger, E. F. Domixo, V. B. HaArstad axi M. E. Mohrman, J. Pharmacol. Exptl. Therap., in the press.

38 G. Rodriguez De Lores Arxaiz, M. Alberici and E. De Robertis, J. Neurochem., I4 (J967) 2 I 5 .

39 E. De Robertis, O. \%. Sellinger, G. Rouriguez De Iores Arnaiz, M. Alberici ANd L. M. ZIEHER, J. Neurochem., I 4 (I967) SI.

40 O. Z. Sellinger and F. De Balbian Verster, J. Binl. Chem., 237 (1962) 2836.

4 I J. D. Uthey, Biochem. Pharmacol., I3 (1964) 1383.

42 A. W. Bernheimer, Arch. Biochem. Biophys, 96 (Ig62) 226.

43 A. D. Bangham A.NI R. M. C. JAwson, Biochim. Biophys. Acta, 59 (1962) Io3.

$4+$ W. D. PeCKham, J. Biol. Chem., 242, (1967) I9o.

45 K. S. l'Rezisindowski, F. IF. Sun and F. L. Crane, Exptl. Cell Res., 50 (I968) $42 \mathrm{I}$.

Biochim. Biophys. Acta, I73 (1969) 176-I 4 